Some Arab and Shawia Remedies and Notes on the Trepanning of the Skull in Algeria. Author(s): M. W. Hilton-Simpson

Source: The Journal of the Royal Anthropological Institute of Great Britain and Ireland, Vol. 43 (Jul. - Dec., 1913), pp. 706-721

Published by: Royal Anthropological Institute of Great Britain and Ireland

Stable URL: http://www.jstor.org/stable/2843547

Accessed: 01-10-2015 10:19 UTC

Your use of the JSTOR archive indicates your acceptance of the Terms \& Conditions of Use, available at http://www.jstor.org/page/ info/about/policies/terms.jsp

JSTOR is a not-for-profit service that helps scholars, researchers, and students discover, use, and build upon a wide range of content in a trusted digital archive. We use information technology and tools to increase productivity and facilitate new forms of scholarship. For more information about JSTOR, please contact support @jstor.org. 


\section{SOME ARAB AND SHAWIA REMEDIES AND NOTES ON THE TREPANNING OF THE SKULL IN ALGERIA.}

By M. W. Hilton-Simpson.

[With Plate XXXiX.]

\section{I.-Arab and Shawia Remedies.}

THE following remedies were noted during a stay of more than two months at El Kantara, "The Mouth of the Sahara," and a journey of one month's duration among the Shawia Berbers of the Wad Abdi and the valley of Bouzina in the western part of the Aurès Mountains in the spring of 1913.

With the single exception of the preventive against hydrophobia all of them were described to me by Arabs or Shawia, who believed implicitly in their efficacy.

As is invariably the case among peoples who are still in a primitive state of culture the border line between medical science and magic is so ill-defined as to be almost non-existent, several of the remedies that I noted, therefore, consist merely in the wearing of charms, "some of which," as Mungo Park says of those found by him in the Sudan, "are, indeed, well calculated to inspire the patient with the hope of recovery, and divert his mind from brooding over his own danger."

I have omitted from this paper all charms that are used to ward off "illness" as a whole and have described only such as are used to prevent or combat some definite disease.

After each remedy will be found, in brackets, the word "Arab" or "Shawia." This signifies that the remedy was described to me by an Arab or Shawia as being in use among his people, but it is not intended to imply that remedies described as "Arab" are unknown to the Shawia or vice versa. The people of El Kantara call themselves Arabs and entertain a certain amount of ill-feeling towards their Shawia (Berber) neighbours, but the El Kantaris so frequently take their wives from among the Shawia that there is in reality a strong infusion of Berber blood at El Kantara, which is very noticeable in the pale complexions of the so-called Arabs, and it seems probable that the Shawia wives may have brought with them Folk-remedies which might be unknown among the purer Arabs inhabiting the Sahara.

MM. Hanoteau and Letourneux, in their work on La Kabylie (vol. i, p. 421), state that such medical knowledge as exists among the Kabyles has largely been introduced by pilgrins who, on their return from Mecca, have stayed for a time in Egypt or Tunis and there picked up a little knowledge which enabled them to practise as doctors upon their return home.

Doubtless the same thing has occurred in the Aurès and in the Sahara, so that it is almost impossible to describe any given remedy as Shawia or Arab when that remedy may have originated in any part of the Mohammedan world. 
On the other hand any remedy which I describe as Shawia and which has not previously been noted from other parts of North Africa or Western Asia may well be indigenous to the Aures.

Fever.-Although Algeria is considered a health resort for Europeans fevers are very common at certain seasons in some parts of the country, especially in the southern oases of the Algerian Sahara. The remedies which I learned for them are partly of a "magical" nature.

1. The feathers of the hoopoe (Arabic " hadhad") are put on the fire while the patient stands over it so that his body is enveloped in the smoke from the burning feathers. (Arab and Shawia.)

The hoopoe is said to migrate from the desert to the Aurès in the summer, when the Shawia endeavour to shoot it. When shot it is "dried" and kept in the house, where its presence brings luck and health and keeps off the "evil eye," so that the feathers must be held to possess some magical virtues in addition to their material usefulness in giving off ammonia while burning, for which practical reason feathers are still burnt in England in cases of faintness.

2. A tuft of wool is cut from between the horns of a black sheep. This is put on the fire while the patient stands in the smoke as in that of the hoopoe feathers. (Shawia.)

3. Oleander leaves are picked before sunrise during the winter fête of Ashura (on the tenth day of the first month of the Mohaminedan year) and are kept tucked away in the rafters of the house. In cases of fever some of these leaves are burned, the patient standing in their smoke as in the above two "cures."

Oleander leaves certainly contain volatile oil, so that in this "cure" there is a substratum of reason which is possibly unknown to the Shawia who employ it. (Shawia.)

4. For the affections of the liver so frequently consequent on fever the following medicine is recommended in the Aurès.

"For liver, when the urine is yellow," take some onions, pound them in a mortar, tie them up in fine cotton material and wring out their juice. Take one coffee cup full of this juice, one coffee cup full of vinegar (white vinegar for preference, but red will serve), and one coffee cup full of olive oil. Mix these three in a bottle.

Take an egg, put it in clean water and leave it there all night. Next morning open the egg very carefully at one end and pour its contents into a cup, then fill the empty eggshell with the mixture from the bottle and drink the dose, immediately afterwards swallowing the raw egg.

This must be done every morning about half an hour before taking the cup of coffee with which most Shawia who can afford the luxury break their fast. In six or seven days a cure is effected. (Shawia.)

The Shawia are as fond of coffee as the Arabs, and the household would have to be exceptionally poor which did not contain one or two of the little china cups, of European manufacture, such as can be seen in any native café in Algeria. These 
cups, which are all more or less of the same size, form a convenient measure in a country where chemists' scales and marked medicine bottles are unknown.

5. For enlarged spleen. - Take the spleen of a goat and lay it upon the patient's left side over his spleen. Then take a "minjel," the small sickle hook with a serrated edge in use all over Algeria, and, having made it very hot in a fire, apply it as in branding to the goat's spleen lying against the patient's side. Repeat this seven times. Then put a number of thorns of a local juniper (? Shawia "Taga," Juniperus oxycedrus) into the goat's spleen so that they stick up from it like pins in a pincushion.

Hang the goat's spleen up in the house so that the patient cannot fail to see it directly he awakes in the morning. When he sees it he must say, "It is my own spleen that grows smaller," for as the goat's spleen dries and shrinks so does that of the patient decrease in size until it resumes its normal proportions. (Shawia.)

Among the Kabyle Berbers, the near relations of the Shawia, branding or "firing" the patient's own side is or has been employed as a remedy for splenic trouble; on p. 425 of the first volume of their work on La Kabylie, MM. Hanoteau and Letourneux state "Contre l'hypertrophie de la rate on met encore en usage les ventouses, ou bien des scarifications sur l'hypocondre gauche avec un instrument trenchant rougi au feu."

It seems very possible that there may be a connection between this operation performed in Kabylie and the magical treatment for splenic trouble that was described to me in the Aurès.

I cannot think it probable that the Shawia formerly practised cautery of the patient's own side for these complaints and subsequently introduced the goat's spleen, thereby converting a surgical operation into a magical rite; it appears far more probable that the Kabyles at one time treated splenic troubles with the goat's spleen, as is now done in the Aurès, but having learned the value of cautery (which is largely used in North Africa for a variety of complaints) came to the conclusion that it could be successfully applied directly to the patient in these cases and so evolved a surgical operation from a form of treatment which may have survived from a time when they were in a very primitive state of culture, an epoch long before the Islamic flood swept over the Barbary States.

The treatment of enlarged spleen by cautery is also mentioned by Major Denham (Travels in Northern and Central Africa, vol. i, p. 157) as having been practised on a Tripolitan merchant in Fezzan.

6. Headache is cured by smearing the pitch extracted from cedar wood on the forehead. (Shawia.)

Cedars are very numerous in the northern part of the Aurès and the method of extracting the pitch is as follows:-

A branch of cedar wood is cut into small pieces with an adze (the usual implement of the country) and the pieces are placed in an earthern bowl which is then turned over on to an earthern plate, to which it is joined with mud in such a way that the pitch can only exude through one channel left in the mud for the purpose. 
The little kiln thus made is covered with brushwood which is set on fire. This process exactly resembles the method of baking Shawia pottery. The fire is kept burning for a long time and when the cedar becomes sufficiently hot the pitch exudes through the channel and runs into a bowl placed ready to receive it. Special pottery vessels are made with a channel formed in them to allow the pitch to run out, but I was unable to see one, and the method described above is, I believe, the usual one employed for extracting cedar pitch.

The pitch is very largely used all over Algeria for dressing sore backs on beasts of burden and is also applied to the interior of goatskin bottles. LieutenantColonel Villot, in his third edition of the Moeurs des Indigènes de l'Algérie (p. 363), describes a similar method of extracting the pitch, and states that, in addition to that of the cedar, the pitch of the juniper and the pine is obtained in the same way.

7. For cold in the head accompanied by a cough, take an ordinary round flat loaf of native bread, quite newly made so that it is pliable; pound some garlic in a mortar and place it in the middle of the loaf ; fold the loaf over on the garlic so that it somewhat resembles the English pastry known as "jam puff," then " cook" it well and eat it while it is very hot without drinking anything. Go to bed and put on a lot of warm coverings. Next day the cold will be cured. (Shawia.)

8. Inhalation is also practised among the Shawia as a cure for colds in the head. Water is poured upon one of the three stones that serve to support cooking pots over the fire while the stone is very hot, the steam that arises is inhaled through the narrow end of one of the plaited halfa grass funnels made for filling goatskin bottles, the wide end being held over the stone and the patient's head enveloped in a burnous to prevent the escape of the steam. (Shawia.)

9. The Arabs around El Kantara recommend the swallowing of raw eggs upon which pepper has been sprinkled as a remedy for colds in the head and they chew cloves in order to prevent coughing. This latter is certainly efficacious. I was first told of it by my shikari when out.stalking gazelle and, having a cough at the time, I tried it with great success, the counter-irritation produced by the cloves certainly checking an almost irresistible inclination to cough which would sometimes come upon me when trying to approach game. The Arab shikaris of El Kantara usually carry cloves with them when hunting. (Arab.)

10. Sore throat: chew the bark of the walnut tree and swallow the juice that exudes from it. (Shawia.)

11. Sore throat. The Shawia put a little of a powdered herb called Noonkha into hot milk and drink it : this is said to be a very rapid remedy for sore throat and also an aid to urination. (Shawia.)

I collected some of this powder and submitted it to Kew, where I was informed that it "consists chiefly of the stem, fruits, etc., of one of the Umbelliferae: Ptychotis atlantica, Cosson." In Monsieur Foureau's catalogue of Arab and Berber names of plants, etc., growing in Algeria I find Nabtha; Nenkha; Nounkha; (Arabic). Ourka (Berber). . . . Ptychotis verticillata. Ombellifères. 
12. The eating of dried meat, which under the name of Khalia is largely used all over North Africa, is considered good for colds, coughs, and pulmonary troubles. (Shawia.)

13. Sore throat.-A chameleon is killed and its flesh dried and powdered. The powder is mixed with water or milk which is used as a gargle, the throat being rubbed with the hand meanwhile. (Shawia.)

14. Sore throat.-Hang the head of a chameleon around the neck on a string to cure sore throats and to keep away illnesses in general from a child. (Shawia.)

15. Chameleons dried, powdered and cooked in eggs are eaten for stomach troubles by the Shawia.

The chameleon is largely used in North Africa both for medicinal purposes and as a charm. Mr. Budgett Meakin in his work on Life in Morocco tells us that "Privet or mallow leaves, fresh honey and chameleons split open alive are considered good for wounds and sores, while the fumes from the burning of the dried body of this animal are often inhaled."

Among the Kabyles of Algeria, according to MM. Hanoteau and Letourneux, a curious custom obtains in accordance with which a man hefore marriage sends to his bride-elect samples of all the wares sold by itinerant pedlars, one of the items in the list given of these being, "Débris de caméléon (tata) antidote contre les maléfices."

16. Whooping cough is treated (1) by drinking hot ass's milk or (2) by cutting the throat of a turtle-dove held in such a position that its warm blood flows into the patient's mouth and down his throat. (Shawia.)

This treatment of a complaint by means of the blood flowing from a creature whose throat has been cut finds a parallel among the Tuareg of the Sahara, also a people of Berber origin who profess the Mohammedan faith. Captain Bissuel on p. 79 of his book on the Touareg de l'Ouest notes that it is enployed by them in cases of fever : "Le malade fait égorger une chèvre, et se place de façon à recevoir, sur la tête, le sang qui retombe sur ses épaules et se répand en suite sur tout le corps."

17. For hocmorrhoids (Arabic "mard el bowesser") take the leaves of the Teselghā (Shawia for Globularia Alypum, L.) and the leaves of the Taga (Shawia for Juniperus oxycedrus, L.), burn them and mix their ashes with oil or water and apply to the anus. This causes considerable pain, but it must be repeated morning and evening, after washing the anus with tepid water, for five or six days, when the patient will be cured. Unless this remedy is applied in the early stages of the complaint it is useless. (Shawia.)

18. Another treatment for hoemorrhoids is to eat a coffee-spoon full of honey, with which powdered garlic has been mixed, early in the morning about half-anhour before breaking the fast; the mixture must also be applied to the anus. This treatment is repeated until a cure is effected, which usually means seven or eight days. (Shawia.)

19. For pain in the stomach I learned only a magical remedy. My informant's 
son was vexed with pain in the left side of the abdomen. An Arab wrote a text from the Koran upon a piece of dried skin taken from a sheep that had been killed for the "Sheep Feast," and bound it over the boy's stomach so that the text lay over the seat of the pain. This put an end to the trouble. (Arab.)

Of course this treatment is the result of a blind faith in the Mohammedan religion on the part of a naturally superstitious people, but, as an instance of the readiness with which natives of Algeria will endow objects which have no connection with their religion with magical powers of healing, I may mention that I have heard of splints applied by a European to a broken limb being kept and subsequently bound to parts of the body which were affected by some complaint in the firm conviction that they possessed healing properties in themselves which would prove useful in the case of any illness from which their owner might suffer.

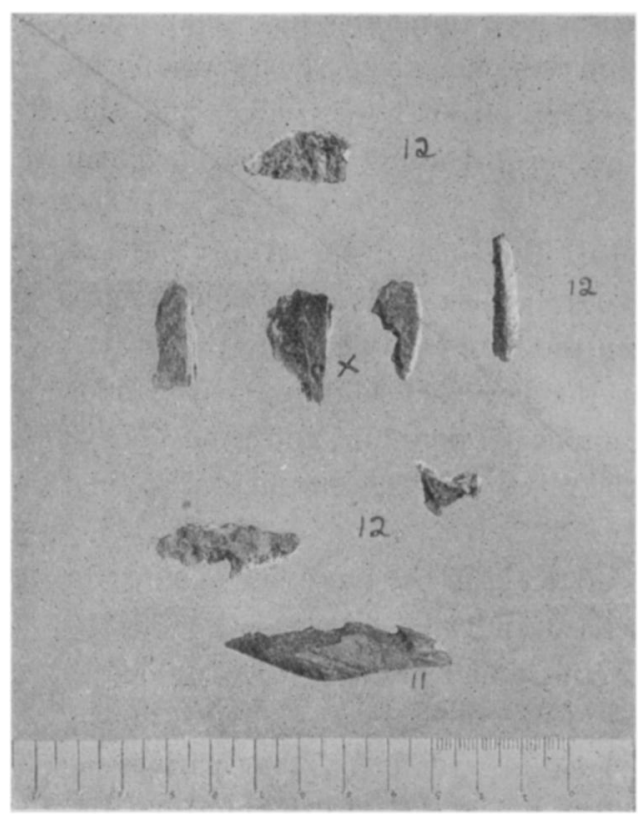

FIG. 1 .

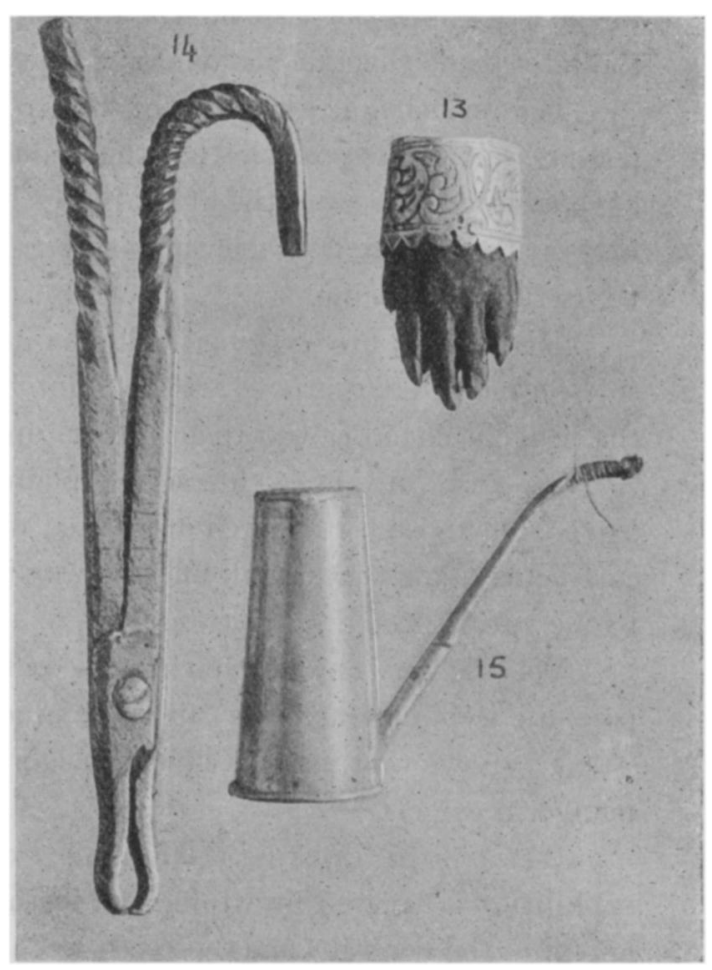

FIG. 2.

20. As elsewhere in North Africa the foot of a porcupine hung over the breast is considered a preventive against and a cure for sore breasts in mothers in Algeria. It is employed as soon as the breast begins to feel sore. The Arabs and Shawia share this belief, but I have been unable up to the present to find any reason for it. One Shawi told me that it is because the porcupine is "the most healthy of beasts."

The foot employed should be the right fore foot of the animal, but the left foot is also used. The one I purchased from a Bedawi near El Kantara (Fig. 2, No. 13) is a left foot and that perhaps accounts for the small price I was asked for it. The 
natives of the Aurès will pay as much as ten francs for a right foot without any silver mounting, which is only put on for ornament and to make the foot more easily attachable to a cord around the neck. The charm is bought by the husband and appears to belong to hin, for he not infrequently lends it to his friends for the use of their wives.

The feet are bought in such large centres as Biskra or Batna.

21. Generally "out of sorts." - Cut the throat of a hedgehog, put the carcase into an earthen pot and put fire over the pot, as in the baking of pottery and the extraction of pitch from cedar wood. Leave the carcase to bake until it is burnt "like charcoal." Powder the burnt carcase, mix it with honey and eat a soupspoonful of the mixture every morning before breakfast. (Shawia.)

22. "Bad eyes."-Take the gall bladder of a hedgehog which has been dried in the sun and make a small tear in the skin of it. Then touch the eye-ball with the interior of the gall bladder thus exposed by the tear in the skin. (Shawia.)

The hedgehog is known in Europe to possess a high immunity to a great many poisons. It seems possible that this immunity may be known to the Shawia, who have, perhaps, observed the animal after having been bitten by a snake, and this may be the reason for their supposition that the burnt body of the hedgehog can be useful in medicine.

Hedgehogs are systematically hunted near Bouzina in the Aurès and are sold for medicinal purposes. The hunter goes out at dusk with a dog which scents the hedgehogs and causes them to curl up, when they are easily captured.

23. Itch (a very common complaint on the heads of children).-Oleander leaves burnt and powdered are mixed with gunpowder, sulphur, and fresh honey; care being taken that no salt finds its way into the mixture. This ointment is applied to the parts affected. (Shawia.)

Volatile oils and sulphur are used, I understand, in England as a cure for parasitic itch and such oils can be obtained from oleander leaves.

I believe that pitch is used in Algeria for itch, and I know it to be applied to mange in camels.

24. A skin disease resembling eczema (not regarded by the natives as syphilitic) is treated by wiping the teeth with the finger early in the morning and applying the deposit from the teeth to the spots. (Arab.)

25. Boils are induced to break and the pus is drawn from them by means of poultices of fresh camel dung warmed over the fire. (Arab.)

Butter mixed with soot is also used for boils. (Arab.)

26. Toothache is cured by inserting a portion of a lump of Hantit into the hollow of the tooth. (Arab and Shawia.)

The Hantit collected consists in lumps of a resinous-looking substance which contains asafoetida. In Mr. Doughty's Wanderings in Arabia, I find mentioned "haltîta, or gum asafœtida, a drug which the Arabs have in sovereign estimation."

The dental forceps illustrated (Fig. 2, No. 14) were obtained among nomad Arabs. 
27. Sprained ankle.-Poultices of mule dung and salt are applied to the ankle. (Arab.)

This remedy was noted at El Kantara where the mule is the ordinary beast of burden, and its dung is therefore easily obtainable. I do not know that any special virtue is believed to belong to the dung of the mule, and I should say that it is only used because it is always at hand.

28. Bruises and strains.-Wrap a piece of camel's fat in cotton material, warm it over a fire and then gently rub the part affected with the cotton containing the fat. I have tried this myself with beneficial results to my knee when bruised and twisted by a fall. (Shawia.)

It would appear that the fat of the camel is considered by the Shawia to be superior to all other fat for this purpose, for the remedy was recommended to me in the higher parts of the Aurès where camels are not to be found, although the fat of goats, sheep, and cattle could easily be procured.

The use of camel's fat must obviously have been learned from the Arabs of the desert.

29. Water on the knee.-Make some oil very hot; wrap a little salt in a rag, dip it in the hot oil and gently "dab" the swollen knee with it. The oil used is presumably that of the olive. Massage is also recommended for water on the knee. (Arab.)

Both these forms of treatment were recommended to me when suffering from water on the knee at El Kantara, but I noted a far more drastic remedy some years ago in the Sahara. One of my camel men (a native of Morocco) had "fired" his knee with a red-hot knife when fluid had formed on it during a long journey, and this treatment had been successful.

30. For cuts and to check bleeding in a wound the ashes of cotton or woollen rag or of paper are applied to the injury. (Arab and Shawia.)

Among the nomad Arabs I collected a paste known as "borhum" which is used to induce cuts to heal. This paste has been examined at Kew and found to consist of a large amount of glucose, some finely powdered inorganic substance, and a few minute fragments of plant tissue. Probably honey is one of its constituents.

31. To induce hair to grow over old sores (e.g., sore backs in mules) a green lizard (known in Shawia as "burriōn") is killed and burnt to ashes, the ashes mixed with oil are applied to the bald patch. The mixture must not be touched with the hand for hair will grow on any part of the body touched by it. (Shawia.)

32. "Cupping" is performed by the barber at Biskra with the aid of the cup (Fig. 2, No. 15). Two rows of four cuts each are made in the back of the patient's neck and the open (wider) end of the cup placed over them, the air being drawn from the cup by sucking the spout in order to induce the blood to flow. This method of cupping is mentioned by Mr. Budgett Meakin as being employed in Morocco, and there is a similar cup to the one illustrated in the Pitt Rivers Museum which comes from Morocco: Cups of this pattern are also used in Arabia. 
33. To ensure conception a whole stem of garlic is wrapped in cotton material and inserted in the vagina, where it remains all night. At dawn it is removed, after which coition takes place. (Shawia.)

34. When the vagina is too large a piece of wool, as dirty as possible, is cut from a sheep and placed in a pot of water to which some alum and a little salt has been added. The woman bathes with this for seven days, at the end of which time the vagina should be as small as that of " a girl of fourteen year's of age." (Shawia.)

Alum and water applied by means of a piece of dirty wool is said to be excellent for washing the vagina, whence it removes all impurities and discharge. It is curious that my informant insisted upon the necessity for dirty wool for the above purposes. (Shawia.)

35. To obtain sexual virility a man will eat a coffee cup full of honey, monkey nuts, and walnuts every morning and evening. (Shawia.) This amounts, of course, to "feeding-up."

36. To prevent hydrophobia the person bitten will take the dead body of the mad dog, and, having slit it open, will insert his feet in its stomach and bind the carcase to his legs, leaving it in this position all night, after which he is said to be free from any risk of infection. (Arab.) This quaint example of sympathetic magic was related to me by a European who has lived for many years in Algeria and speaks Arabic most fluently.

Although they do not, perhaps, come strictly under the heading of "Medical Notes," I may here describe two love philtres and a charm to produce madness, which were told to me by a Shawi in the Aurès.

1. Love philtre:-When a donkey foal of either sex is born there is a small lump of " meat" (i.e., after-birth) upon its forehead. This lump, which is easily removable without any detriment to the foal, is taken away as soon as the foal's head appears by whoever is lucky enough to be at hand to procure it. It is then salted, dried in the sun, and kept to be sold in small pieces at a high price to those who require a love philtre. It is powdered and secretly put into the food of the person upon whom it is intended to act. The substance is known in the Shawia dialect as "Khorej." It is much sought after by young people of both sexes and by wives who wish to retain the affections of their husbands.

A young man will pay an old woman to invite the lady of his heart to a meal and administer the philtre in her food; women will bribe the landlord of a café to give it to one of his customers in his coffee or tea.

The man or woman on whose behalf the charm is to be used must rub the Khorej round his (or her) heart seven times-counting aloud-in order to ensure that it will work for him (or her) only.

My informant, having given me the above details, added later that a little semen of the user and the summit of a cone of sugar could be advantageously added to the powdered Khorej. The cone of sugar, no doubt, is used on account of the resemblance, slight though it be, which it bears to the male organ. (Shawia.) 
While we were staying with a well-known marabout in the Aurès a donkey foal was born in the holy man's stables. One of his retainers secured the Khorej, which is now in the Pitt Rivers Museum, but he was obliged to maintain the strictest secrecy as to what he had done, for all marabouts disapprove most strongly of the use of these philtres, which they consider (probably with reason) to be the cause of a good deal of domestic trouble. The Khorej is, however, very well known and appears to be frequently used among the Shawia.

2. Love philtre.-A woman who wishes to retain her husband's affections goes by night to a fresh tomb, cuts off the right forearm of the corpse (of either sex) and stirs her husband's kus-kus with the dead hand in order that his heart may be dead to all other women. (Shawia.) I have described this philtre exactly as I noted it from my Shawi informant, and I was able to learn nothing further about it except that it, like the Khorej, is forbidden by the marabouts and by religion. It seems to bear some resemblance to a practice which, I am told, is common in Egypt. In that country a man will secure the hand of a corpse and cause his wife to step across it seven times in order to ensure conception.

3. Hyena's brains are secretly mixed with a person's food in order to send him mad. From this madness there is no recovery. (Shawia.) This custom, which Mr. Budgett Meakin mentions as existing in Morocco, may possibly have its origin in the similarity between the "laugh" of a hyena and that of a maniac.

\section{II.-Trepanning of the Skull among the Nomad Arabs of Algeria.}

When I went to Algeria this year (1913) I determined to try to obtain for the Pitt Rivers Museum specimens of the instruments with which the Shawia have for a long time past been accustomed to perform the operation of the trepan. Drs. Malbot and Verneau have described the operation in L'Anthropologie, VIII, 1897, p. 174, as being performed by Shawia of the Djebel Cherchar in the eastern portion of the Aurès Mountains, and they state that surgeons who have learnt their art in this district are to be found in practice over a great part of the Aurès and in the desert as far as the Wad Rhir and the Wad Souf to the south and south-east of Biskra.

I expected, therefore, to obtain the instruments I wanted (if indeed I was able to obtain them at all) from the hands of a Berber surgeon.

On arriving in Algeria I learned from a French doctor in the Government service that trepanning is practised in the south-western portion of the Aurès, in villages within easy reach of $\mathrm{El} \mathrm{Kantara,} \mathrm{where} \mathrm{I} \mathrm{was} \mathrm{staying,} \mathrm{but} \mathrm{I} \mathrm{was} \mathrm{told} \mathrm{that}$ the natives were extremely reticent about the doings of their surgeons, and that it was improbable that I should succeed in meeting one of then or in seeing his instruments.

I was agreeably surprised, therefore, when I found that I had made friends with two surgeons in the second village I visited, and that they were not only 
willing to discuss their operations, but were quite ready to part with such of their instruments as they could spare.

As I believe these instruments are extremely rare in collections I give a careful description of each of them in the course of this paper, as well as a photograph of those now in the Pitt Rivers Museum.

I was astonished to find that the surgeons I met were Arabs. They belong to a large tribe of nomads who wander with their numerous flocks of sheep and goats over a wide area of country to the south of El Kantara, and who own two or three villages in the oases whence they obtain their supply of dates.

This tribe is said by Colonel de Lartigue, in his work on L'Aures, to have migrated from Morocco about the year 1500 of our era, but the people stoutly affirm that they are Arabs, and with the exception of a few of the poorer classes, who remain in the villages as guardians of the date plantations, they live the same life in their tents of goats' hair as the Bedawin Arabs farther south in the Sahara.

When I mentioned to my surgeon friends that I had imagined the operation of the trepan to be performed exclusively by the Shawia they denied that this was the case, and told me that it was known " all over the desert."

Of course it may be that the Shawia of the Djebel Cherchar originally disseminated surgical knowledge throughout the Sahara, and, as Drs. Malbot and Verneau suggest, may have practised the operation of the trepan from time immemorial in their Aures home, but, on the other hand, it must be remembered that the Arabs overran the Djebel Cherchar on more than one occasion, and, settling down in the district, mingled with the original Berber inhabitants (Colonel de Lartigue, L'Aurès).

It seems possible, therefore, that the Arabs introduced their surgery among the Berbers, but it is very difficult to determine finally to what race trepanning in Algeria owes its origin from the limited evidence at present available, for there have been so many conquerors of Barbary who have left their mark upon the country.

According to Colonel de Lartigue descendants of Roman colonists were found by the Arabs in the Djebel Cherchar in the eleventh century; many of the "educated" Shawia hold the belief that their race is descended from the Romans; and Drs. Malbot and Verneau describe as being practised in the Aurès a method of trepanning by means of adjacent perforations with the drill which was not mentioned to me by the Arabs but which closely resembles a method referred to by Percivall Pott in his Chirurgical Works (vol. i, p. 157 et seq.), as being employed by the "ancients" and in connection with which he quotes from Oribasius, a Greek who lived, I think, about A.D. 400.

Upon the scanty evidence we possess, therefore, it seems almost impossible to form an opinion as to the origin of trepanning in North Africa. That information as to Shawia and Arab surgery and medicine is not easily obtainable is due to the suspicion with which the native practitioners regard the French doctors, who would, of course, be interested in studying their methods. 
When once the natives have become convinced of the superiority of European medicine and surgery the local doctors' livelihood will be gone; it is not to be wondered at, therefore, that the native practitioners do not love the Government doctors and do their best to prevent their patients from putting themselves in their hands. With this object they encourage the belief, so commonly held in Algeria, that if a native goes to a European hospital with an injured limb that limb will probably be amputated. To the Arab and Shawia death is preferable to the loss of a limb.

Cases are not wanting in which a native has been cured by an Arab surgeon after the European doctor has pronounced the amputation of the limb to be necessary. One of these came under my notice in which the operation was perforned by one of the Arabs from whom I purchased instruments and who enjoys a very wide reputation for his skill in removing pieces of damaged bone from a limb as well as for his success in trepanning.

It appears that the sheykh of his village received a gunshot wound at close quarters in the left upper arm while travelling in the train. He was taken to the hospital, where he was told that his arm must be amputated at the shoulder. With an Arab's horror of amputation he decided to return home and be treated by the native doctor rather than remain in hospital and lose his arm. The native doctor removed several pieces of damaged bone from the arm and the sheykh recovered. I saw the arm myself, and although the scar was very large and deep the sheykh informed me that he suffered no inconvenience at all as a result of the wound and operation.

The same surgeon had successfully removed a large piece of bone from the tibia of a woman's leg (which piece of bone I collected, see Fig. 1, No. 11) and also some fragments from the forearm of a man who showed me the scars.

Both these two operations were necessitated by gunshot wounds.

Cases like the above, especially that of the sheykh, do much to keep alive surgery among the Arabs even in districts whence a European doctor can be reached without a very long journey.

Before relating the information given to me on the subject of trepanning I will describe in detail the instruments I collected, which are illustrated in Plate XXXIX.

These are nine in number and all bear unmistakable signs of having been used. Most of them appear to have been sterilized in fire, for there are marks of burning upon their wooden handles which, from their appearance, could scarcely have been made when the blades were hafted.

1. Scalper (Arabic name "matabaa").-A cylinder of iron about $\frac{11}{16}$ inch in depth and $1 \frac{3}{8}$ inches in diameter, made of a strip of iron with one sharp edge, bent round until the ends touch without being joined. Where the ends meet one end is joined by fusion on its blunt edge to a round bar of iron about 13 inches long, so that the cylinder is at right angles to the bar. The other end of the bar passes through a round wooden handle, 4 inches in length, and is bent round at right 
angles to prevent this handle from slipping off. The instrument roughly resembles a large " wad-punch."

2. Retractor (Arabic name "shefīra").-An iron blade projecting about $2 \frac{1}{2}$ inches from a round wooden handle $3 \frac{1}{8}$ inches in length. The blade where it joins the handle is rectangular in section and about $\frac{1}{8}$ inch wide, but it gradually becomes flatter and wider until at the distal end it is about $\frac{3}{8}$ inch wide, the end being slightly rounded at the corners and presenting a fairly sharp edge. This end is bent over at right angles to the rest of the blade to form a hook. The whole blade slopes slightly backwards from the handle.

3. Retractor (Arabic name "shefïra").-An iron blade projecting about $1 \frac{3}{4}$ inches from a round wooden handle $1 \frac{5}{8}$ inches long. For $1 \frac{1}{8}$ inches of its length the blade is rectangular in section and about $\frac{1}{8}$ inch wide, but the distal end is flat, widening abruptly to a width of $\frac{3}{8}$ inch, and is bent round at right angles forming a hook, the fairly sharp edge of which is slightly rounded at the corners.

4. Hook or retractor (Arabic name "mongesh").-An iron blade about $1 \frac{15}{16}$ inches long inserted in a lathe-turned wooden handle presumably of European origin. Where it joins the handle the blade is rectangular in section and about $\frac{1}{4}$ inch wide, but it narrows towards the distal end which is little more than $\frac{1}{16}$ inch in width. The distal end is bent sharply round to form a small hook.

5. Drill, also used as an elevator (Arabic name "hērwer̂l").-An iron blade about $2 \frac{3}{4}$ inches long projecting from a round wooden handle $3 \frac{1}{4}$ inches in length. Where it joins the handle the blade is $\frac{1}{4}$ inch wide and it gradually increases to a width of $\frac{3}{8}$ inch near the distal end. It narrows abruptly (leaving a "shoulder" on each side) at the distal end so that the last $\frac{3}{16}$ inch of the blade is only $\frac{1}{8}$ inch wide. This end is rounded and has a cutting edge. The "shoulders" on the blade would serve to prevent too deep a hole being made through the skull when the instrument is used as a drill.

6. Saw (Arabic name "monshar" or "menshar").-An iron blade projecting $3 \frac{7}{8}$ inches from a round wooden handle $2 \frac{7}{8}$ inches long. The blade is rectangular in section where it joins the handle and is about $\frac{1}{8}$ inch wide. It curves downwards almost at right angles 2 inches from the handle and then curves outwards again at the distal end where the blade is flat with a serrated lower edge containing eleven teeth. The serrated edge forms a segment of a circle, the teeth being upon the convex edge.

7. Saw (Arabic name "monshar" or "menshar").-Very similar to No. 6. An iron blade $4 \frac{5}{8}$ inches long inserted in a wooden handle about $2 \frac{3}{4}$ inches long. The eurves in this saw are not so sharp as in No. 6 ; there are thirteen teeth on its convex edge. Neither of these two saws is sharp.

8. Saw (I do not know any special Arabic name for this form of saw so I presume it is called "monshar" or " menshar").-An iron blade $2 \frac{1}{4}$ inches in length with a round wooden handle $3 \frac{7}{8}$ inches long. The blade for $1 \frac{1}{4}$ inches from the handle is rectangular in section and about $\frac{1}{8}$ inch wide; the last $\frac{7}{8}$ inch of the blade is a flat rectangular surface with three serrated edges. The teeth are fine and sharp. 
9. Elevator (Arabic name "mhez").-A flat iron blade about $\frac{3}{16}$ inch wide protruding about $1 \frac{3}{8}$ inches from a round wooden handle $2 \frac{1}{2}$ inches long. The distal end curves very slightly indeed and is fairly sharp. Its corners are not rounded but one of them has been broken off.

The above instruments I was told by both my surgeon friends are all that are necessary for trepanning, but I ought, perhaps, to add to the list a tenth implement collected at the same time. The real function of this tool (a sharp pointed iron blade in a wooden handle, Plate XXXIX, No. 10) is to smooth down the transverse woollen threads on the loom when weaving a burnous, but its point would render it useful for piercing the skull in lieu of the "herrwerrl" or, used as a probe, for testing the depth of the holes drilled or cuts made with the saw. My reason for including it in the list of instruments is that after I had purchased some trepanning instruments from the less celebrated of the two surgeons he sent me this tool as a present. I had not discussed anything but trepanning with him and I had attempted to purchase no specimens other than surgical instruments in the village, I cannot understand, therefore, why the surgeon should have given me this tool unless he used it in his profession. From its appearance I am sure it has actually been used in weaving, but it seems quite possible that it has served for surgical purposes as well, although I have no direct evidence of this.

The method of trepanning a head was described to me as follows :-

The first thing to be done is to remove a portion of the scalp in order to expose the place to be trepanned. This is effected by making the "punchlike" instrument " matabaa" (1) white hot in a fire and placing it firmly, like a branding iron, on the head, a flicking movement of the instrument then removes the piece of scalp thus burnt round. The great heat, as well as sterilizing the "matabaa," also prevents excessive bleeding from the scalp. The retractors, "shefïra" (2 and 3), are then used to draw away the scalp around the place to be trepanned in order to give room for the use of the saw. I presume that the hook "mongesh" (4) is also used for this purpose. A hole is then drilled in the skull by spinning the drill, "her̄wer̄l " (5), between the palms of the hands. This, I am told, is to let out any pus and blood that may be under the skull, but I imagine the hole thus made would also be useful as a starting place for the saw.

The saw is then applied to the "good" bone just clear of the injured part. Only a very small arnount is sawn through, after which the elevator (9) or the hook (4) is inserted in the incision and, if possible, the "bad" bone slightly raised in order to let out pus and blood.

Great care is taken that the dura mater be not pierced, for my informant told me that the patient must die if this is done.

Only the small incision with the saw described above is made on the first day, but next day and on each succeeding day the process is repeated until the whole of the "bad" bone has been removed.

So little is sawn through each day that it takes from fifteen to twenty days to remove a portion of the skull as large as a penny piece. 

hook.

The part sawn away is lifted from the head with the elevator or the

When the "bad" bone has at last been removed, no artificial bone or plate is placed over the cavity, but the skin is induced to re-form over the wound by the daily application of fresh dressings of a mixture of honey and butter, and the stem and leaves of a herb powdered as fine as snuff.

The herb, which I collected in its powdered form, grows locally upon the hills and is a species of Labiatæ.

The daily dressing is continued sometimes for as long as one month, at the end of which time the patient is cured.

No form of anæsthetic is used. I could find no evidence of any attempt to sterilize the saw, the retractors, or the elevator (unless we accept the burns on the handles of the instruments as an indication that they have been purposely sterilized in fire) and the rags used as bandages are of the dirtiest description. The surgeon does not wash his hands as a rule either before or after dressing a wound.

The more celebrated of the two surgeons I met told me that he sometimes trepans as many as five or more heads in one year, the nature of the cases being usually heads "broken" by blows from sticks or stones. He also told me that operations for the removal of damaged bone from the arm or leg are performed in the same manner and with the same instruments as trepanning. This surgeon presented me with some fragments of skull removed from the head of a man now living (Fig. 1, No. 12).

Upon one of these fragments, marked with a $\times$ in the illustration, is an incision apparently made by twisting some instrument pressed hard against the skull after the manner already described of drilling a hole with the "herwēil." The fragment of skull is not perforated, however, so that the incision cannot have been made to let out pus and blood, but would appear from its position to have been used as a starting place for the saw.

This incision must have been made with a trident drill such as Irs. Malbot and Verneau describe as being in use among the Shawia. Of course the two surgeons only sold to me such instruments as they could spare and it seems probable that they possess the drill in several different forms.

I was not fortunate enough to witness the actual trepanning of a head, but I did see a case in which the operation had been commenced.

The patient was a boy about fourteen years old who had been knocked down by a train some twenty miles away fifteen days before I saw him, His right leg had been broken and he had received terrible injuries to the left side of his head.

The leg had been set and was in splints, but the limb was so much wrapped up in old clothes, etc., that I could not ask to see it.

The hut in which the boy lay was very dark so that I was not able to see the wound very clearly when the bandages were removed from his head, but I could 


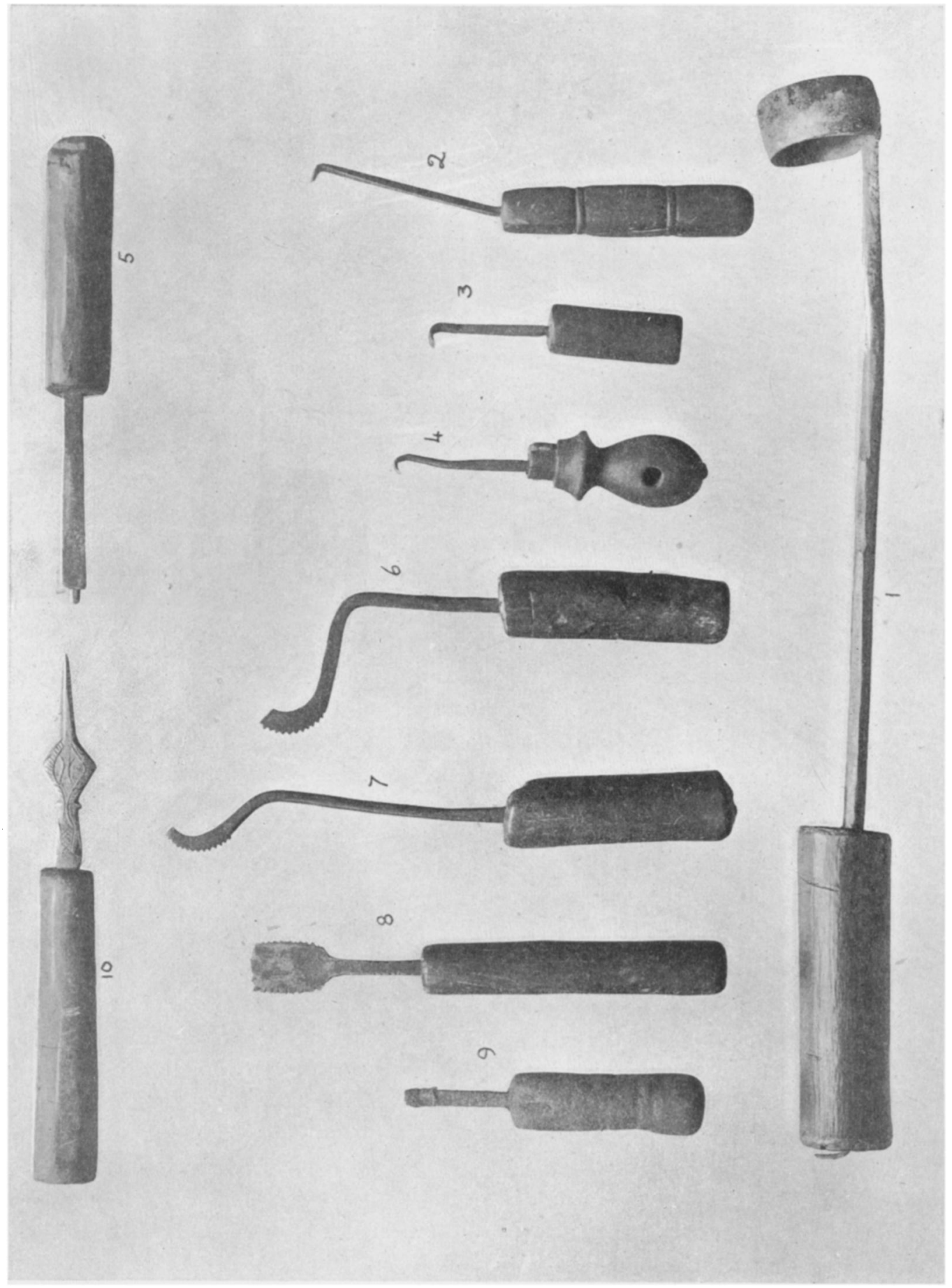


make out that a portion of the scalp had been neatly taken away and a clean edge of bone showed where some pieces of the skull had already been removed.

The boy was able to eat, talk a little, and pull himself up to a sitting position by means of a cord suspended from the roof.

The surgeon entertained no doubt whatever that his patient would ultimately recover.

The fact that the boy had lived for over a fortnight with the terrible injuries he had received, rendered more awful by a twenty-mile journey over rough country (presumably on the back of a mule) and by the daily treatment he was undergoing without an anæsthetic, clearly proves that a life of privation and hardship makes the nomads hard.

The surgeon took me to see this patient in the hope that I might be able to supply him with some drug to check the bleeding when the operation was resumed. This may seem to indicate that the Arabs have nothing of this nature themselves other than the ashes of rags or paper, but I cannot venture an opinion on this subject until I have had a further opportunity of studying their surgery.

The instruments I collected differ slightly from those described by Drs. Malbot and Verneau in L'Anthropologie.

The most usual form of drill employed by the Shawia of the Djebel Cherchar is, these authors state, in the form of a small trident, the centre prong of which is longer than the other two. Such an instrument, which is figured in L'Anthropologie, must have produced the hole in the piece of skull (Fig. 1, No. 12) to which I have referred above, and must therefore, be known to the Arabs too. This Shawia drill appears to be somewhat superior to that which I collected, for its handle is divided into two parts, the blade and the lower portion of the handle being loosely socketed in the upper part so that the drill can be easily caused to rotate by spinning the lower part of the handle between the palms while the instrument is held against the skull by pressure of the operator's forehead or chin on the upper portion of the handle. The drill collected by me has a simple wooden handle.

On the other hand the saws I obtained among the Arabs are not quite so primitive as those figured in L'Anthropologie, although their principle is the same.

Drs. Malbot and Verneau state that sometimes the use of the scalping knife, which they say is usually employed, is replaced by destruction of the scalp by means of a red hot iron, but they make no mention of a special instrument used for this purpose such as the "matabaa" (1).

The French authors declare that the native surgeons are exceedingly successful in trepanning, and they quote an instance of a woman undergoing the operation in order to manufacture evidence for divorce proceedings against her husband.

My Arab friend told me when I left him that I must be careful when following the instructions he had given me as the operation was " a little bit dangerous," but he certainly did not consider it a critical one. 